\title{
Long-term trends of subsoil radon in Kamchatka as indicators for the preparation of earthquakes with $M>7.5$ at the northwestern framing of the Pacific Ocean
}

\author{
Pavel P. Firstov*1 \\ Evgeniy O. Makarov ${ }^{1,2}$
}

\author{
${ }^{1}$ Kamchatka Branch of the Federal Research Centre "United \\ Geophysical Survey of the Russian Academy of Sciences", \\ Petropavlovsk-Kamchatsky, Russia \\ ${ }^{2}$ Kamchatka State University named after Vitus Bering, \\ Petropavlovsk-Kamchatsky, Russia \\ *E-mail: firstov@emsd.ru
}

\begin{abstract}
Pезюме RUS
The paper presents the results of the volume activity monitoring of subsoil radon at the strainsensitive point of the Paratunka control station (PRTR) for 2000-2020. Emanation observations are carried out at this point in order to search for precursors of strong earthquakes in subsoil radon variations. The preparation of earthquakes at the northwestern framing of the Pacific Ocean with a source depth $\mathrm{H}<200 \mathrm{~km}$ and $M_{\mathrm{w}}>7.5$, and of a lower magnitude in some cases, which have occurred at the distances up to $1000 \mathrm{~km}$ from PRTR, is reflected in the dynamics of radon volume activity (RVA) in the form of trends lasting from 8 months to 3 years. The behavior of RVA dynamics in the last 5 years points to a possible earthquake with $M_{\mathrm{w}}>7.5$ in the Pacific Ocean in the vicinity of the eastern coast of the Kamchatka Peninsula, which may occur before February 1, 2021. This conclusion is consistent with a long-term seismic forecast for the Kuril-Kamchatka seismogenic zone, made in the works of S.A. Fedotov and A.V. Solomatin [2017, 2019], according to which the highest probability of an earthquake with $M_{\mathrm{w}} \geq 7.7$ falls on the Avacha Bay and Southern Kamchatka.
\end{abstract}

\section{Keywords}

Kamchatka Peninsula, subsoil radon, moisture saturation zone, long-term trends, precursor, earthquake

For citation: Firstov P.P., Makarov E.O. Long-term trends of subsoil radon in Kamchatka as indicators for the preparation of earthquakes with $M>7.5$ at the northwestern framing of the Pacific Ocean. Geosistemy perehodnykh zon $=$ Geosystems of Transition Zones, 2020, vol. 4, no. 3, pp. 270-287. (In Russ. \& Engl.). https://doi.org/10.30730/gtrz.2020.4.3.270-278.279-287

Для цитирования: Фирстов П.П., Макаров Е.О. Долговременные тренды подпочвенного радона на Камчатке как индикаторы подготовки землетрясений с $\mathrm{M}>7.5$ в северо-западном обрамлении Тихого океана. Геосистемы переходных зон, 2020, т. 4, № 3, с. 270-287.

https://doi.org/10.30730/gtrz.2020.4.3.270-278.279-287

\section{References}

1. Adushkin V.V., Spivak A.A. 2014. Fizicheskie polia v pripoverkhnostnoi geofizike [Physical fields in near-surface geophysics]. Moscow: GEOS, 349 p. (In Russ.).

2. Baykara O., İnceöz M., Doğru M., Aksoy E., Külahcı F. 2009. Soil radon monitoring and anomalies in East Anatolian Fault System (Turkey). J. of Radioanalytical and Nuclear Chemistry, 1(279): 159-164. https://doi.org/10.1007/s10967007-7211-2

3. Biryulin S.V., Kozlova I.A., Yurkov A.K. 2019. Investigation of informative value of radon volume activity in soil during both the stress build-up and tectonic earthquakes in the South Kuril region. Vestnik KRAUNTS. Nauki o Zemle = Bulletin of KRAESC. Earth Sciences, 4(44): 73-83. https://doi.org/10.31431/1816-5524-2019-4-44-73-83 (In Russ.). 
4. Box G., Jenkins G. 1974. Analiz vremennykh riadov. Prognoz i upravlenie [Time series analysis. Forecasting and control]. Moscow: Mir, 406 p. (In Russ.).

5. Chebrov V.N., Kugaenko Yu.A., Abubakirov I.R., Droznina S.Ya., Ivanova E.I., Matveenko E.A., Mityushkina S.V., Ototyuk D.A., Pavlov V.M., Raevskaya A.A. et al. 2016. The January 30, 2016 earthquake with $\mathrm{Ks}=15.7, M \mathrm{w}=7.2$, $\mathrm{I}=6$ in the Zhupanovsky region (Kamchatka). Vestnik KRAUNTS. Nauki o Zemle = Bulletin of KRAESC. Earth Sciences, 1(29): 5-16. (In Russ.).

6. Chebrov D.V., Kugaenko Yu.A., Abubakirov I.R., Lander A.V., Pavlov V.M., Saltykov V.A., Titkov N.N. 2017. The July 17, 2017 Near-Aleutian earthquake with $\mathrm{Mw}=7.8$ on the border of the Komandor seismic gap (western part of the Aleutian Arc). Vestnik KRAUNTS. Nauki o Zemle = Bulletin of KRAESC. Earth Sciences, 3(35): 22-25. (In Russ.).

7. Chebrov D.V., Kugaenko Yu.A., Lander A.V., Abubakirov I.R., Droznina S.Ya., Mityushkina S.V., Pavlov V.M., Saltykov V.A., Serafimova Yu.K., Titkov N.N. 2020. The Uglovoye Podnyatiye earthquake on December 20, 2018 $(\mathrm{Mw}=7.3)$ in the junction zone between Kamchatka and Aleutian oceanic trenches. Vestnik KRAUNTS. Nauki o Zemle = Bulletin of KRAESC. Earth Sciences, 1(45): 100-117. (In Russ.). https://doi.org/10.31431/1816-5524-2020-1-45100-117

8. Cicerone R.D., Ebel J.E., Beitton J.A. 2009. Systematic compilation of earthquake precursors. Tectonophysics, 476: 371-396. doi:10.1016/j.tecto.2009.06.008

9. Fedotov S.A., Solomatin A.V. 2017. The long-term earthquake prediction for the Kuril-Kamchatka island arc for the April 2016 through March 2021 period, its modification and application; the Kuril-Kamchatka seismicity before and after the May 24, 2013, M 8.3 deep-focus earthquake in the Sea of Okhotsk. J. of Volcanology and Seismology, 11(3): 173-186. https://doi.org/10.1134/s0742046317030022

10. Fedotov S.A., Solomatin A.V. 2019. Long-term earthquake prediction (LTEP) for the Kuril-Kamchatka island arc, June 2019 to May 2024; properties of preceding seismicity from January 2017 to May 2019. Development and Practical Application of the LTEP Method. J. of Volcanology and seismology, 6: 6-22. https://doi.org/10.31857/s02030306201966-22.

11. Firstov P.P. 2014. Forecasting of large earthquakes based on radon monitoring in the Petropavlovsk-Kamchatsky geodynamical testing area. Vestnik KRAUNTS. Nauki o Zemle = Bulletin of KRAESC. Earth Sciences, 1(23): 35-49. (In Russ.).

12. Firstov P.P., Makarov E.O. 2015. Reaction of radon in soil and groundwater to stress-strain state of the Earth's crust. Seismicheskie pribory = Seismic Instruments, 51(4): 58-80. (In Russ.).

13. Firstov P.P., Makarov E.O. 2018. Dinamika podpochvennogo radona na Kamchatke i sil'nye zemletriaseniia [Dynamics of subsoil radon in Kamchatka and strong earthquakes]. Petropavlovsk-Kamchatsky: KamGU n.a. Vitus Bering, 148 p. (In Russ.).

14. Firstov P.P., Makarov E.O., Glukhova I.P. 2017. Peculiarities of subsoil gas dynamics before the M = 7.2 Zhupanovo earthquake on January 30, 2016, Kamchatka. Doklady Akademii nauk = Doklady Earth Sciences, 472: $196-199$. https://doi.org/10.1134/s1028334x17020015

15. Firstov P.P., Makarov E.O., Glukhova I.P., Budilov D.I., Isakevich D.V. 2018. Search for predictive anomalies of strong earthquakes according to the monitoring of subsoil gases at Petropavlovsk-Kamchatsky geodynamic test site. Geosistemy perehodnykh zon = Geosystems of Transition Zones, 2(1): 16-32. (In Russ.). doi:10.30730/25418912.2018.2.1.016-032

16. Immè G., Morelli D. 2012. Radon as earthquake precursor. In: D’Amico S. (ed.) Earthquake research and analysis statistical studies, observations and planning, 143-160. https://doi.org/10.5772/29917

17. Iwata D., Nagahama H., Muto J., Yasuoka Y. 2018. Non-parametric detection of atmospheric radon concentration anomalies related to earthquakes. Scientific Reports, 8(13028). https://doi.org/10.1038/s41598-018-31341-5

18. İnan S., Akgu T., Cemil S. 2008. Geochemical monitoring in the Marmara region (NW Turkey): A search for precursors of seismic activity. J. of Geophysical Research, 113: B03401. https://doi.org/10.1029/2007JB005206

19. Kissin I.G. 2011. Strain sensitivity in fluid-saturated media. J. of Volcanology and Seismology, 5(3): 179-189. doi:10.1134/S0742046311030055.

20. Majumdar K. 2004. A study of fluctuation in radon concentration behavior as an earthquake precursor. Current science, 9(86): 1288-1292.

21. Parovik R.I. 2014. Matematicheskie modeli klassicheskoi teorii emanatsionnogo metoda [Mathematical models of the classical theory of emanation method]. Petropavlovsk-Kamchatskiy: KamGU n.a. Vitus Bering, 128 p. (In Russ.).

22. Petraki E., Nikolopoulos D., Panagiotaras D., Cantzos D., Yannakopoulos P., Nomicos C., Stonham J. 2015. Radon222: A potential short-term earthquake precursor. J. of Earth Science and Climatic Change, 6(6): 000282. doi:10.4172/2157-7617.1000282

23. Piersanti A., Cannelli V., Galli G. 2016. The Pollino 2012 seismic sequence: clues from continuous radon monitoring. Solid Earth, 7: 1303-1316. https://doi.org/10.5194/se-7-1303-2016

24. Popruzhenko S.V., Zubin M.I. 1997. Tectonics and seismicity of shelf in the gulf of Avacha and adjacent areas. J. of Volcanology and Seismology, 19(2): 211-219.

25. Rudakov V.P. 2009. Emanatsionnyi monitoring geosred i protsessov [Emanation monitoring of geomedia and processes]. Moscow: Nauchnyi mir [Scientific world], 175 p. (In Russ.).

26. Tsunomori F., Tanaka H., Murakami M., Tasaka S. 2011. Seismic response of dissolved gas in groundwater. In: Proceedings of the 10th Taiwan-Japan International Workshop on Hydrological and Geochemical Research for Earthquake Prediction, October 25, Taiwan, National Cheng Kung University. Tainan, 29-35. 
27. Wakita H. 1981. Precursory changes in ground water prior to the 1978 Izu-Oshima-Kinkai earthquake. Earthquake Prediction: An Intern. Review, 4: 527-532. https://doi.org/10.1029/ME004p0527 